\title{
Spatial Distribution Trend of Plankton in Sungai Pulai Estuary, the Straits of Johor, Malaysia
}

(Pola Taburan Reruang Plankton di Muara Sungai Pulai, Selat Johor, Malaysia)

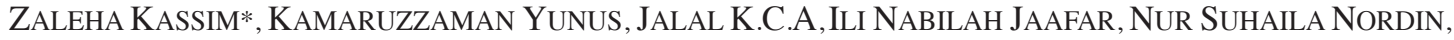 \\ WAN MUHAMAD AMIR Wan AHMAD, AHMAD ISMAIL \& AKBAR B. JOHN
}

\begin{abstract}
A spatial distribution study was carried out to investigate the influence of some environmental factors to planktons using collected samples from the Sungai Pulai estuary, near to the Singapore boarder. Six stations chosen for the field sampling were Port Tanjung Pelepas (S1), Tanjung Bin Charcoal Plant (S2), seagrasses of Pulau Merambong (S4) and SecondLink Bridge (S5) and mangrove areas $(S 3, S 6)$. There is no significant difference of phytoplankton abundance (p $>0.05)$ between stations. Instead, it differs significantly at the level of $\mathrm{p}<0.05 ; \mathrm{p}=0.0001$ (Two tailed, $t=14.10 \mathrm{df}=34)$ between sampling session. In contrast, there is a significant difference of zooplankton abundance $(\mathrm{p}<0.05)$ in the sampling stations $\left(\chi^{2}=17.3,(5)\right)$, but there is no significant difference $(\mathrm{p}>0.05 ; \mathrm{p}=0.8966)$ between the sampling session (Two tailed, $t=0.1310, d f=34)$. Biplot analysis shows that most species are associated with the stations except for Protoperidinium $s p$., Lithodesmia $s p$. and Alexendrium $s p$. Copepod species including Microcalanus $s p$., Calanus $s p$. and Temora $s p$. are associated with S5. Paracalanus $s p$., Euterpina $s p$., Tigriopus $s p$., Oithona $s p$. and Pseudocalanus $s p$. are associated with S1, S2 and S4. The planktons are correlated with the temperature (Pearson's correlation, $r^{2}=-0.897$ ) and salinity (Pearson's correlation, $\left.r^{2}=0.9416\right)$ in March but no correlation is found in November sampling session. The results indicated the important role of certain environmental factors, namely the salinity and temperature to the distribution of the planktons in Sungai Pulai estuary.
\end{abstract}

Keywords: Copepod; distribution; estuary; plankton; Sungai Pulai

\section{ABSTRAK}

Suatu kajian taburan reruang telah dijalankan untuk meninjau pengaruh alam sekitar ke atas plankton menggunakan sampel plankton yang diperoleh dari muara Sungai Pulai, berhampiran sempadan Singapura. Sebanyak enam stesen pensampelan telah dipilih iaitu Pelabuhan Tanjung Pelepas (S1), Kilang Arang Tanjung Bin (S2), kawasan rumput laut Pulau Merambong (S4) dan juga Jambatan Lingkaran ke-2 (S5)serta kawasan hutan bakau (S3, S6). Tiada perbezaan bererti bagi kelimpahan fitoplankton ( $\mathrm{p}>0.05)$ antara stesen $\left(\chi^{2}=5.547,(5)\right)$ tetapi perbezaan bererti didapati pada tahap $\mathrm{p}<0.05 ; \mathrm{p}=0.0001$ (Two tailed, $t=14.10 \mathrm{df}=34$ ) antara sesi pensampelan. Sebagai bandingan, terdapat perbezaan bererti untuk kelimpahan zooplankton $(\mathrm{p}<0.05)$ di antara stesen $\left(\chi^{2}=17.3,(5)\right)$ tetapi zooplankton tidak menunjukkan perbezaan bererti $(\mathrm{p}>0.05 ; \mathrm{p}=0.8966)$ antara sesi pensampelan (Two tailed, $t=0.1310, d f=34)$. Analisis biplot pula menunjukkan kebanyakan spesies fitoplankton berkait dengan stesen-stesen kecuali Protoperidinium sp., Lithodesmia $s p$. dan Alexendrium sp. Spesies Kopepod termasuk Microcalanus sp., Calanus sp. dan Temora sp. berkait dengan S5. Paracalanus $s p$., Euterpina $s p$., Tigriopus sp., Oithona sp. dan Pseudocalanus sp. menunjukkan kaitannya dengan S1, S2 dan S4. Plankton adalah berkait dengan suhu (Pearson's correlation, $r^{2}=-0.897$ ) dan kemasinan (Pearson's correlation, $\left.r^{2}=0.9416\right)$ dalam bulan Mac tetapi tiada kaitan ditunjukkan pada bulan November. Keputusan kajian ini menunjukkan kepentingan peranan faktor persekitaran tertentu iaitu kemasinan dan suhu terhadap taburan plankton di kawasan muara Sungai Pulai.

Kata kunci: Kopepod; muara; plankton; Sungai Pulai; taburan

\section{INTRODUCTION}

Zooplankton is the second in the trophic level of marine food-web after the primary producer, the phytoplankton. Copepods which are known as the main group in zooplankton (Zou et al. 2006) could directly consume the phytoplankton (deYoung et al. 2004; Üstün \& Bat 2014). Both phyto-and zooplankton are influenced by the environmental factors in their distribution and assemblage (Hsieh et al. 2004; Mwaluma et al. 2003). The presence of ports, power plant and other similar activities in coastal areas would give effect to at least the water physic-chemical parameters such as salinity and temperature which further influence the planktons (Choi et al. 2012; Jiang et al. 2009, 2008). It is hypothesised that the water quality in areas 
with industrial activities will be different from those with natural habitat such as seagrass and mangroves.

The present paper aimed to report the distribution trend of phyto- and zooplankton inhabiting the Sungai Pulai estuary in The Straits of Johor and how the environmental parameters in the study area affect the communities. The estuary is located in a busy Straits of Johor where there are ports, power plant and factories at Malaysia and Singapore sides thus made the study relevant.

\section{MATERIALS AND METHODS}

Two field samplings were conducted at six selected stations in Sungai Pulai estuary (Figure 1) in November 2013 and March 2014. Six sampling stations represented a possible different water environment (Table 1) were selected to cover the $22.6 \times 2.83 \mathrm{~km}$ river and estuary area.

In the field, YSI multi-probe meter was used to measure the water parameters including temperature, salinity, $\mathrm{pH}$ and dissolved oxygen (DO). The depth of the light penetration was measured using the Secchi disc. The 20 and $100 \mu \mathrm{m}$ nets were used to obtain the phyto- and zooplankton samples. All samplings were carried out in the morning time during the high tide. Phytoplankton and zooplankton samples were fixed with a Lugol's iodine and $5 \%$ buffered formalin, respectively.
Phytoplankton cell counting was done using a haemocytometer under a compound microscope. Zooplankton samples were diluted to $1 \mathrm{~L}$ before a subsampling strategy is carried out to get only $1 / 32$ parts for quantification. Examination and counting was made under a dissecting microscope using a Bogorov tray. All data were analysed statistically using SPSS version 21 .

\section{RESULTS}

\section{ENVIRONMENTAL PARAMETERS}

Table 2 summarizes the environmental condition of the estuary during the study period. Dissolved oxygen (DO) and $\mathrm{pH}$ shows in good condition for organism to survive and grow. Light penetration is up to $2.00 \mathrm{~m}$ depth particularly in November. Temperature (range of $29.09-29.71^{\circ} \mathrm{C}$ ) has the fluctuation of less than $1^{\circ} \mathrm{C}$. Salinity (range of 29.21 $32.39 \mathrm{ppt}$ ) follows the contrast trend as the temperature, become more salty in March than in November.

\section{DISTRIBUTION PATTERN OF PLANKTON SPECIES}

A total of 12 and 14 phytoplankton species were identified during the first and second sampling session, respectively. Five species (Pleurosigma sp., Chaetoceros

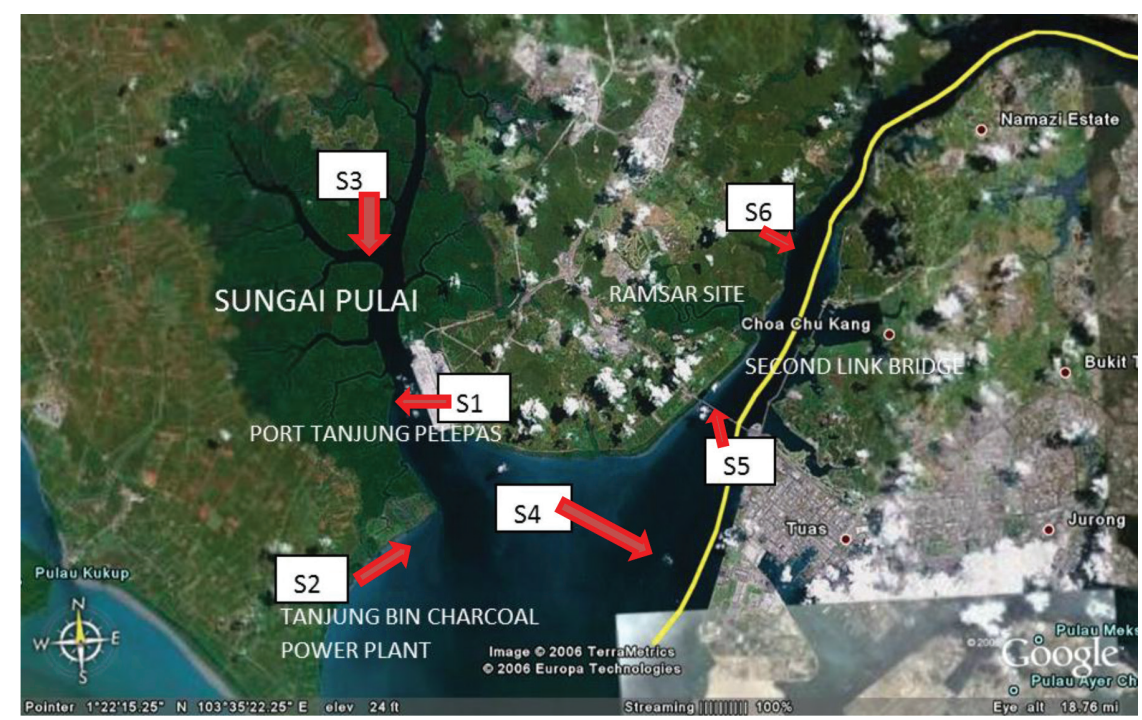

FIGURE 1. Six sampling stations in Sungai Pulai estuary, the Johor Straits, Peninsular Malaysia

TABLE 1. Sampling stations in Sungai Pulai estuary and the environmental condition/ human activities ( $\mathrm{S}$ - station)

\begin{tabular}{ll}
\hline Sampling station & Site description \\
\hline $\mathrm{S} 1\left(\mathrm{~N} 01^{\circ} 20.714^{\prime} \mathrm{E} 103^{\circ} 32.431^{\prime}\right)$ & Coastal area of Port Tanjung Pelepas \\
$\mathrm{S} 2\left(\mathrm{~N} 01^{\circ} 19.844^{\prime} \mathrm{E} 103^{\circ} 32.742^{\prime}\right)$ & Coastal area of Tanjung Bin Charcoal Power Plant \\
$\mathrm{S} 3\left(\mathrm{~N} 01^{\circ} 23.885^{\prime} \mathrm{E} 103^{\circ} 32.718\right)$ & Upper reach of Sungai Pulai \\
$\mathrm{S} 4\left(\mathrm{~N} 01^{\circ} 18.977^{\prime} \mathrm{E} 103^{\circ} 36.599^{\prime}\right)$ & Seagrass bed of Merambong island \\
$\mathrm{S} 5\left(\mathrm{~N} 01^{\circ} 20.976^{\prime} \mathrm{E} 103^{\circ} 37.800^{\prime}\right)$ & Seagrass bed under the Second Link Bridge \\
$\mathrm{S} 6\left(\mathrm{~N} 01^{\circ} 22.529^{\prime} \mathrm{E} 103^{\circ} 38.362^{\prime}\right)$ & Mangroves area in inner part of the Johor Straits \\
\hline
\end{tabular}


TABLE 2. Water parameter at each sampling station in Pulai River estuary in November 2013 and March 2014

\begin{tabular}{|c|c|c|c|c|c|}
\hline \multirow{2}{*}{ Station } & \multicolumn{5}{|c|}{ Water parameter } \\
\hline & Temperature $\left({ }^{\circ} \mathrm{C}\right)$ & Salinity (ppt) & $\mathrm{DO}(\mathrm{mg} / \mathrm{L})$ & $\mathrm{pH}$ & Light depth (m) \\
\hline \multicolumn{6}{|l|}{$1^{\text {st }}$ Sampling (November 2013) } \\
\hline S1 Port of Tanjung Pelepas & 29.31 & 29.32 & 4.18 & 7.29 & 1.50 \\
\hline S2 Tanjung Bin Charcoal Power Plant & 29.65 & 30.64 & 5.25 & 7.58 & 0.50 \\
\hline S3 Upper reach of Sungai Pulai & 29.34 & 30.54 & 5.82 & 7.42 & 2.00 \\
\hline S4 Merambong Island & 29.66 & 29.21 & 4.10 & 7.69 & 2.00 \\
\hline S5 Second Link Bridge & 29.71 & 31.69 & 3.95 & 7.39 & 0.70 \\
\hline S6 Mangrove Area & 29.57 & 29.70 & 5.13 & 7.75 & 0.90 \\
\hline \multicolumn{6}{|l|}{$2^{\text {nd }}$ Sampling (March 2014) } \\
\hline S1 Port Tanjung Pelepas & 29.34 & 32.39 & 6.38 & 7.96 & 1.50 \\
\hline S2 Tanjung Bin Charcoal Power Plant & 29.29 & 32.35 & 5.54 & 8.21 & 1.00 \\
\hline S3 Upper reach of Sungai Pulai & 29.09 & 32.35 & 2.56 & 8.19 & 0.50 \\
\hline S4 Merambong Island & 29.09 & 31.84 & 4.94 & 8.41 & 0.75 \\
\hline S5 Second Link Bridge & 29.64 & 31.22 & 3.82 & 8.40 & 1.00 \\
\hline S6 Mangrove Area & 29.20 & 30.82 & 3.14 & 8.34 & 1.00 \\
\hline
\end{tabular}

sp.,Pseudonitzschia sp., Thalassionema sp.\& Cosanodiscus sp.) were found in both but other 14 species occurred in separate sampling session. Skeletonema sp. dominated the sampling area with the highest percentage of contribution $(89.31 \%)$ to the phytoplankton community. Zooplankton was dominated by the copepods which contributing more than $95 \%$ of the composition. Out of the 8 calanoid species, the highest percentage occurred during the first sampling was the Oithona sp. (37.24\%), followed by Microcalanus sp. $(26.63 \%)$ and Paracalanus sp. (15.56\%). On the second sampling, Microcalanus sp. maintained its dominance in S1, S3, S5 and S6 with the highest percentage of 31.91\% in S5.

Biplot analysis shows the different distribution trend for phytoplankton and zooplanktonic copepods (Figures 2 \& 3). Phytoplankton species are separated into two groups, those which are closely associated with the sampling stations and those which are not. The later include Protoperidinium, Lithodesmia, Ditylum, Eupodisca and Pseudonitzia. Biplot analysis shows almost all of the copepod species associated with all stations except for Acartia sp. which is associated only with S6. Eurytemora sp. and Microsetella sp. are quite far from any station but Macrosetella sp. is not associated at all with any station.

Kruskal-Wallis test found that there is no significant difference in phytoplankton abundance between stations $\left(\chi^{2}=5.547,(5)\right), p>0.05$. The nonparametric Mann Whitney Test indicates that there is a significant different of abundance between March and November sampling $(U=$ $18776, p<0.05), p<0.05$. In term of density, phytoplankton seemed to be in higher abundance in March (range of mean abundance $515.12-1166.05 \times 10^{3} \mathrm{cell} / \mathrm{mL}$ ) than in November (range of mean abundance $388.89-536.11 \times 10^{3}$ cell $/ \mathrm{mL})$. The highest abundance $\left(1166.05 \times 10^{3} \mathrm{cell} /\right.$ $\mathrm{mL}$ ) was found in S3, the upper reach of Sungai Pulai (Figure 2). Stations with industrial activities (S1, S4, S5) comparatively showed high abundance of phytoplankton

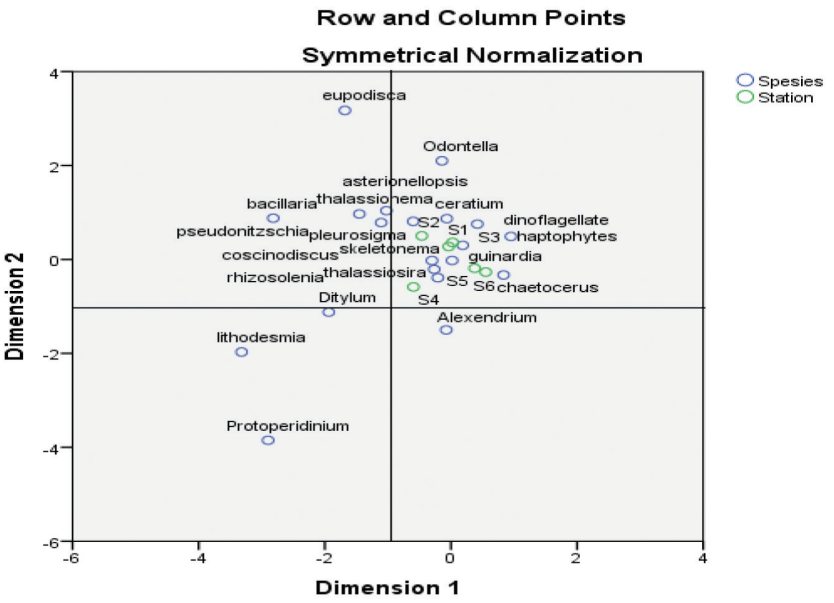

FIGURE 2. Biplot analysis for species of phytoplankton and sampling stations (S1-S6) in Sungai Pulai estuary 


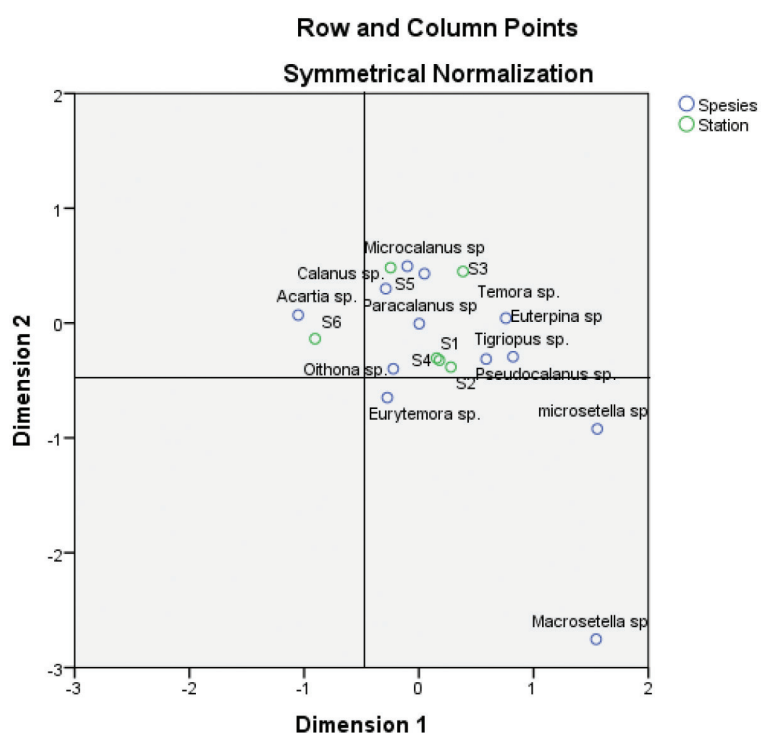

FIGURE 3. Biplot analysis for species of zooplankton and sampling stations (S1-S6) in Sungai Pulai estuary

except for S2 in the charcoal power plant area. In this station the abundance was comparatively low for both sampling sessions.

In contrast to the above results, there is a significant difference of copepod abundance between station $\left(\chi^{2}=\right.$ $17.3,(5)), p<0.05$. The abundance in $\mathrm{S} 2$ is significantly different if compared with S3 and S4. S3 is different from S5 and S6. S4 is also significantly different from S6. Nonetheless, there is no significant difference of zooplankton abundance between the sampling period $(U$ $=18670.5, p>0.05), p>0.05$.

\section{RELATIONSHIP BETWEEN ABUNDANCE AND ENVIRONMENTAL PARAMETERS}

Pearson's correlation analysis summarizes the possible relationship between the abundance of planktons and the environmental parameters during the sampling period. Copepods are significantly correlated to the temperature in the estuary in November $\left(r^{2}=-0.897, p<0.05\right)$. Copepods increase their abundance in cooler environment. During the same period, phytoplankton significantly correlated with the salinity $\left(\mathrm{r}^{2}=0.9416, p<0.05\right)$ indicating that in the area of more marine water, the abundance of phytoplankton will be more. In contrast to the results, none of the environmental parameters have significant correlation with the plankton abundance in March.

\section{DISCUSSION}

Environmental condition in the Straits, particularly Sungai Pulai estuary is notably comparable to the tropical estuary condition as reported earlier (Arshad et al. 2011; Zaleha et al. 2013, 2009). The water parameter is most likely related to the monsoon (Yoshida et al. 2006;
Zulikha et al.2013) and the daily salinity and temperature change (Behera et al. 2013).

The phytoplankton abundance is significantly higher when the environment became more salty in March than in November. This could be related to the species which determined the different biochemical response towards salinity exposure (Lionard et al. 2005). At the same time salinity influenced the nutrient uptake by the phytoplanktons for their growth (Marcarelli et al. 2006). Moreover, different phytoplankton species would have preference to different nutrient amount at different salinity (Ganguly et al. 2013; Melo et al.2007). In a coastal power station in the north part of the Malacca Straits, the salinity combined with other factors to correlate positively with the phytoplankton abundance (Muhammad Adlan et al. 2012). On the other hand, Härnström et al. (2009) highlighted the role of tide and water level which then influence the species composition and abundance of the phytoplankton species in a sampling site.

Sungai Pulai estuary is very near to the Singapore water which is reported as having experience in toxic dinoflagellate incident (Holmes \& Teo 2002), thus the occurrence of the dinoflagellate species (Alexandrium sp. \& Protoperidinium sp.) and certain diatom (Pseudonitzschia) is worth noted. Other phytoplankton species which are associated with most of the studied area in the estuary indicate the common occurrence as reported before (Gin et al. 2003, 2000). The moderate grazing activity of copepod community which is shown by the copepod species in the area could also affect the phytoplankton population density (Li et al. 2003).

The number of copepods species found in the present study is much lower than the recent report from Johan et al. (2013) or the earlier report of Zaleha et al. (2008). The copepod distribution as found in the present study 
could indicate on how copepods would travel following their food source (Fetcher et al. 2004; Zamora-Terol et al. 2014). The co-occurrence would also imply the mixing condition of open and coastal water in the estuary (Arshad et al. 2011). O'boyle and Silke (2010) and Ooi et al. (2010) showed the role of tides in controlling the algal abundance in Singapore water. The condition might be important to maintain the composition of plankton species in the Sungai Pulai estuary. The copepods could be more influenced by the diet brought in by the sea current and tide (Araujo et al. 2008; Ara et al. 2011). These include diet such as the detritus (preferred by Acartia sp.) and picoplankton (preferred Parvocalanus sp.).

It is interesting to find that zooplankton correlated negatively with the temperature increase which is in the fluctuation range of less than $1^{\circ} \mathrm{C}$. As reported earlier, copepods such as Acartia tonsa usually has a wide range of tolerance in salinity and temperature (Holste \& Peck 2006). The existence of coastal power plants could significantly increase the sensitivity of the copepods to thermal stress. Choi et al. (2012) found that thermal stress would significantly cause mortality to Acartia sp. Jiang et al. (2009) proved the negative effect of coastal power plant toward particularly the calanoid copepod composition and species diversity. Jiang et al. (2008) also showed how thermal stress from coastal power plant could affect the temperature tolerance in marine copepods which seem to be species specific. The sensitivity towards the temperature could be related to the life history traits of the copepod species (Lee et al.2003). Further investigation on the seasonal effect of coastal power plants to the phyto- and zooplankton interaction would explain more on how the organism regulate their population abundance in such ecosystem.

\section{CONCLUSION}

Despite the limited study period, the present finding is able to improve our knowledge on the influence of the environmental condition to the planktons in Sungai Pulai estuary and potentially in relation to the coastal industrial area. Phytoplankton abundance is significantly different between periods of sampling while zooplankton differed significantly between stations. Phytoplankton could be influenced by the increase of salinity while zooplankton seemed to be influenced by the decrease of temperature. Planktons show their response towards the water parameters particularly in March. Seasonal monitoring is suggested for the interaction of phyto-and zooplankton as to understand the adaptability of the organism to the ecosystem with such industrial activities in Sungai Pulai and the Johor Straits.

\section{ACKNOWLEDGEMENTS}

The research is part of the study on the 'Bioluminescent Plankton from The Straits of Johor' supported by the ERGS grant (2013-2015), Ministry of Education Malaysia.

\section{REFERENCES}

Ara, R., Arshad, A., Musa, L., Amin, S.M.N. \& Kuppan, P. 2011. Feeding habits of larval fishes of the family Clupeidae (Actinopterygii: Clupeiformes) in the estuary of River Pendas, Johor, Malaysia. Journal of Fisheries and Aquatic Science 6(7): 816-821.

Araujo, H.M.P., Nascimento-Vieira, D.A., Neumann-Leitão, S., Schwamborn, R., Lucas, A.P.O. \& Alves, J.P.H. 2008 Zooplankton community dynamics in relation to the seasonal cycle and nutrient inputs in an urban tropical estuary in Brazil. Brazilian Journal of Biology 68(4): 751-762.

Arshad, A., Ara, R., Amin, S.M.N., Effendi, M., Zaidi, C.C. \& Mazlan, A.G. 2011. Influence of environmental parameters on shrimp post-larvae in the Sungai Pulai seagrass beds of Johor Strait, Peninsular Malaysia. Scientific Research and Essays 6(26): 5501-5506.

Behera, M.R., Chun, C., Palani, S. \& Tkalich, P. 2013. Temporal variability and climatology of hydrodynamic, water property and water quality parameters in the West Johor Strait of Singapore. Marine Pollution Bulletin 77(1): 380-395.

Choi, K-H., Kim, Y-O., Lee, J-B., Wang, S-Y., M-W., Lee, P-G., Lee, D-S., Ahn, Hong, J-S. \& Soh, H-Y. 2012. Thermal impacts of a coal power plant on the plankton in an open coastal water environment. Journal of Marine Science and Technology 20(2): 187-194.

deYoung, B., Heath, M., Werner, F., Chai, F., Megrey, B. \& Monfray, P. 2004. Challenges of modeling ocean basin ecosystems. Science 304: 1463-1466.

Fechter, A., Thistle, D., Arlt, G., Suderman, K. \& Vopel, K. 2004. Do harpacticoids (copepoda) use water-borne cues to aid in locating food parcels? Marine Ecology 25(3): 217-223.

Ganguly, D., Robin, R.S., Kanuri Vishnu Vardhan, Pradipta R. Muduli, Abhilash, K.R., Sivaji Patra \& Subramanian, B.R. 2013. Variable response of two tropical phytoplankton species at different salinity and nutrient condition. Journal of Experimental Marine Biology and Ecology 440: 244-249.

Gin, K.Y.H., Zhang, S. \& Lee, Y.K. 2003. Phytoplankton community structure in Singapore's coastal waters using HPLC pigment analysis and flow cytometry. Journal of Plankton Research 25(12): 1507-1519.

Gin, K.Y.H., Lin, X. \& Zhang, S. 2000. Dynamics and size structure of phytoplankton in the coastal waters of Singapore. Journal of Plankton Research 22(8): 1465-1484.

Härnström, K., Karunasagar, I. \& Godhe, A. 2009. Phytoplankton species assemblages and their relationship to hydrographic factors - A study at the old port in Mangalore, coastal Arabian Sea. Indian Journal of Marine Sciences 38(2): 224-234.

Holmes, M.J.\& Teo, S.L.M. 2002. Toxic marine dinoflagellates in Singapore waters that cause seafood poisonings. Clinical and Experimental Pharmacology and Physiology 29(9): 829-836.

Holste, L. \& Peck, M.A. 2006. The effects of temperature and salinity on egg production and hatching success of Baltic Acartia tonsa (Copepoda: Calanoida): A laboratory investigation. Marine Biology 148(5): 1061-1070.

Hsieh, C-H., Chiu, T-S. \& Shih, C-T. Copepod diversity and composition as indicators of intrusion of the Kuroshio Branch Current into the Northern Taiwan Strait in Spring 2000. Zoological Studies 43(2): 393-403.

Jiang, Z-B., Zeng, J-N., Chen, Q-Z., Huang, Y-J., Liao, Y-B., Xu, X-Q. \& Zheng, P. 2009. Potential impact of rising seawater temperature on copepods due to coastal power plants in subtropical areas. Journal of Experimental Marine Biology and Ecology 368(2): 196-201. 
Jiang, Z-B., Zeng, J-N., Chen, Q-Z., Huang, Y-J., Xu, X-Q., Liao, Y-B., Shou, L. \& Liu, J-J. 2008. Tolerance of copepods to short-term thermal stress caused by coastal power stations. Journal of Thermal Biology 33(7): 419-423.

Johan, I., Abu Hena, M.K., Idris, M.H. \& Arshad, A. 2013. Taxonomic composition and abundance of zooplankton Copepoda in the coastal waters of Bintulu, Sarawak, Malaysia. Journal of Fisheries and Aquatic Science 8(3): 472-479.

Lee, H-W., Ban, S., Ikeda, T. \& Matsuishi, T. 2003. Effect of temperature on development, growth and reproduction in the marine copepod Pseudocalanus newmani at satiating food condition. Journal of Plankton Research 25(3): 261-271.

Li, C., Wang, R. \& Sun, S. 2003. Grazing impact of copepods on phytoplankton in the Bohai Sea. Estuarine, Coastal and Shelf Science 58(3): 487-498.

Lionard, M., Muylaert, K., van Gansbeke, D. \& Vyverman, W. 2005. Influence of changes in salinity and light intensity on growth of phytoplankton communities from the Schelde River and Estuary (Belgium/The Netherlands). Hydrobiologia 540(1-3): 105-115.

Marcarelli, A.M., Wayne, W.A. \& Olivia, G. 2006. Salinity controls phytoplankton response to nutrient enrichment in the Great Salt Lake, Utah, USA. Canadian Journal of Fisheries and Aquatic Sciences 63(10): 2236-2248.

Melo, S., Bozelli, R.L. \& Esteves, F.A. 2007. Temporal and spatial fluctuations of phytoplankton in a tropical coastal lagoon, southeast Brazil. Brazilian Journal of Biology 67(3): 475-483.

Muhammad Adlan, A.H., Wan Maznah, W.O., Khairun, Y., Chuah, C.C., Shahril, M.H. \& Mohd Noh, A. 2012. Tropical marine phytoplankton assemblages and water quality characteristics associated with thermal discharge from a coastal power station. Journal of Natural Sciences Research 2(10): 88-99.

Mwaluma, J., Osore, M., Kamau, J. \& Wawiye, P. 2003. Composition, abundance and seasonality of zooplankton in Mida Creek, Kenya. Western Indian Ocean Journal of Marine Science 2(2): 147-155.

O’Boyle, S. \& Silke, J. 2010. A review of phytoplankton ecology in estuarine and coastal waters around Ireland. Journal of Plankton Research 32(1): 99-118.

Ooi, B.H., Zheng, H., Yue, K.P., Kurniawati, H., Sundarambal, P., Dao, M.H., Roopsekhar, K.A.P., Wei, J., Cho, W., Tkalich, P., Malanotte-Rizzoli, P. \& Patrikalakis, N.M. 2010. Case study of phytoplankton blooms in Serangoon Harbor of Singapore. Proceedings of OCEANS IEEE. pp. 1-6.

Üstün, F. \& Bat, L. 2014. The egg production rate of Acartia (Acartiura) clausi Giesbrecht, 1889 (Copepoda) in Sinop Peninsula (Southern Black Sea). Turkish Journal of Fisheries and Aquatic Sciences 14: 605-613.

Yoshida, T., Tatsuki, T., Md Yusoff, F. \& Othman, B.H.R. 2006. Seasonal variation of zooplankton community in the coastal waters of the Straits of Malacca. Coastal Marine Science 30(1): 320-327.

Zaleha, K., Abang Jefri, A.M. \& Hasimah, M.S. 2013. Fauna of Porcellidiidae (Copepoda: Harpacticoida) from Sungai Pulai, Malaysia. The Malayan Nature Journal 64(4): 159-167.
Zaleha, K., Farah Diyana, M.F., Amira Suhaili, R. \& Amirudin, A. 2009. Benthic community of the Sungai Pulai seagrass bed, Malaysia. Malaysian Journal of Science 28(2): 143-159.

Zaleha, K., Sulong, I., Mohd Lokman, H., Kamaruzaman, B.Y. \& Mohd Afendy Baba. 2008. Species composition and abundance of planktonic copepods in Pahang Estuaries, Malaysia. Journal of Sustainability Science and Management 3(1): 11-22

Zamora-Terol, S., Mckinnon, A.D. \& Saiz, E. 2014. Feeding and egg production of Oithona spp. in tropical waters of North Queensland, Australia. Journal of Plankton Research 36(4): 1047-1059.

Zou, L., Zhang, J., Pan, W-X. \& Zhan, Y-P. 2001 . In situ nutrient enrichment experiment in the Bohai and Yellow Sea. Journal of Plankton Research 23(10): 1111-1119.

Zulikha, N.Z., Yusoff, F.M., Nishikawa, J., Arshad, A. \& Matias-Peralta, H.M. 2013. Mesozooplankton composition and abundance in a tropical estuary during monsoon season. Journal of Fisheries and Aquatic Science 8(3): 430-440.

Zaleha Kassim*, Kamaruzzaman Yunus \& Jalal, K.C.A. Marine Science Department, Kulliyyah of Science International Islamic University Malaysia Jalan Sultan Ahmad Shah 25200 Kuantan, Pahang Darul Makmur Malaysia

Ili Nabilah Jaafar, Nur Suhaila Nordin \& Wan Muhamad Amir Wan Ahmad

School of Fisheries and Aquaculture Sciences

Universiti Malaysia Terengganu

21030 Kuala Terengganu, Terengganu Darul Iman Malaysia

Ahmad Ismail

Biology Department, Faculty of Environmental Sciences Universiti Putra Malaysia 43400 Serdang, Selangor Darul Ehsan Malaysia

Zaleha Kassim*, Kamaruzzaman Yunus, Jalal, K.C.A. \& Akbar B. John

INOCEM, International Islamic University Malaysia

Jalan Sultan Ahmad Shah

25200 Kuantan, Pahang Darul Makmur

Malaysia

*Corresponding author; email: drzack@iium.edu.my

Received: 14 March 2015

Accepted: 11 May 2015 